DOI: doi.org/10.18372/38223

UDC: 625.7

\title{
3.9 FEATURES OF INTERACTION OF ORGANIC BINDER AND SLAG FILLER
}

\author{
Kateryna Krayushkina ${ }^{1}$, Andriy Belyatynsky ${ }^{2}$, Tetiana Khymeryk ${ }^{2}$
}

In conditions of constant development of the road transport followed by fast increase in the scope of truck fleet, increase in carrying capacity and dynamic features of cars, overall performance of vehicles to a great extent depends on riding qualities of motor roads which is assessed with regard to strength, evenness and roughness. The dominant role here belongs to asphalt pavements protecting road structure from direct effect of climatic factors impact and ensuring design speeds.

Asphalt pavements well proved themselves in the most complicated activity of road operational services during winter period when due to slipperiness formed on the surface of the road pavement, significant reduction in vehicles speed, traffic intervals and increase in the number of road accidents took place that negatively affected economic parametres of the state.

One of priority tasks of road branch is increasing operational reliability of motor roads during different seasons of the year. The main ways of of this task solution is application of asphalt pavements having sufficient durability that allows to ensure standard riding qualities and improvement of of road pavement design for the purpose of reduction of winter slipperiness formation.

Recently, in connection with increasing cost of road-building materials, the most actual problem in highway engineering was a wide application of local materials. In the regions with well developed iron and steel industry the most widespread local materials are coproducts of black and nonferrous metallurgy, that are the slags. Numerous researches define possibility of their use for preparation of asphalt mixes.

Use of asphalt concrete with slag materials is restricted for the pavements of the III-rd technical category highways and for lower road categories by existing regulations. This results from the fact that the properties of asphalt concrete with slag materials as road-building materials are considered in comparison with the properties of asphalt concrete on traditional (granite mineral) materials and insufficientl attention is given to studying operational and deformatsion-strength properties of asphalt pavements with slag materials, especially on the highways of the highest categories.

The urgency of the problem which is considered can be explained by the fact that in the regions with highly developed iron and steel industry the use of asphalt concrete with slag materials in the pavements of highways allows to gain certain economy of funds at their construction and maintenance, and also helps to solve the problem of metallurgical industry waste use.

Asphalt concrete with slag materials is an artificial construction conglomerate, which is a mixture of different types of metallurgical slags and bitumen, produced under certain technological conditions, laid and compacted in the upper layers of road pavement.

The study of the possibility of using metallurgical slag in asphalt concrete is the work of many scientists and the author: Belyatynsky, Krayushkina, Eremina, Korolev, Rastegayeva, Samodurov, Yudina, Hushek, Kandhal, Li et al. (2012), Sivilevicius et al. (2011), Shen et al. (2009), Sofilid et al. (2011), Takahashi et al. (2011), Wang et al. (2011), Wu et al. (2007). As a result of literary analysis, a fairly wide range of metallurgical slags was considered.

Based on the study of physical and mechanical properties, the possibility of using different types of metallurgical slags for the preparation of hot and cold asphalt concrete has been proved.

Of all types of slags of ferrous and nonferrous metallurgy, blast furnace slags, which are less prone to different types of decay, are most suitable for road construction. Slag materials with desired properties are obtained by controlling the speed of the cooling process of the slag melt. 
The cooling rate determines the chemical, hydraulic activity of the material, its physicomechanical properties, structure and mineralogical composition, as well as features of interaction with bitumen in asphalt concrete. With rapid cooling, the slag melt turns into sand with a grain size of $0-2.0 \mathrm{~mm}$, which has high hydraulic properties. During the slow cooling of the slag melt, heat energy is mainly spent on crystallization processes. The material is gaining high strength, but largely loses its hydraulic knitting properties.

Asphalt concrete with slag materials, as well as asphalt concrete from traditional materials, is divided into crushed-stone (fine-grained, coarse-grained) and sandy. Slag crushed stone, sand (natural or slag) and mineral powder are present in the crushed stone asphalt concrete as a mineral part. In the sandy asphalt concrete, at the base of the mineral part, there are slag, slag-and-sand sands and granulated slags. Depending on the laying temperature of asphalt concrete with slag materials, mixtures can be hot and cold.

Studying asphalt concrete with slag materials, all the above authors note the following: while maintaining the regularities inherent in asphalt concrete from traditional materials, the properties of asphalt concrete with slag materials are determined by the type of slag, its structure and porosity, which determine the nature of its interaction with bitumen.

The high chemical activity of slags and the high content of adsorption centers, in the form of divalent and trivalent cations $\mathrm{Ca}^{+2}, \mathrm{Mg}^{+2}, \mathrm{Fe}^{+2}, \mathrm{Fe}^{+3}$, leads to the formation of a solid bitumen mineral material. In the interaction of bitumen with slag materials, the physical and chemical sorption bonds that have been formed firmly hold the bitumen film on the surface of the mineral material. The high porosity of slag materials, when combined with bitumen, leads to filtration of the binder and its components in the middle of the grains of the mineral material.

In the process of filtration, the oils penetrate through the capillaries into the grains to the greatest depth, the resins, due to their lower mobility and greater activity, penetrate to a lesser depth. Having a developed porous structure, slag crushed stone in asphalt concrete contributes to a more complete conversion of bitumen to a structured state. At the same time, due to selective diffusion of bitumen, enrichment of the structured layer with asphaltenes occurs. Selective filtration of bitumen components leads to the formation of more rigid and less elastic bitumen films on the surface of the slag aggregate.

The interaction of bitumen with slag aggregate leads to the realization of physical, mechanical, chemical, electrostatic and diffusion processes; as a result, adhesive bonds at the bitumen - mineral interface become durable and resistant to climatic factors, both at the time of combining and in time. The nature of the slag crushed stone surface, the viscosity of bitumen and its interaction with mineral material provide asphalt concrete with high indicators of internal friction angle $\varphi$ (from $40^{\circ}$ to $50^{\circ}$ ), which exceeds the value for asphalt concrete prepared using granite crushed stone (from $33^{\circ}$ to $41^{\circ}$ ).

The dependence of bitumen capacity indicators on the structural and textural signs of slag rubble was established: slag of a pumice-shaped structure with a porosity of $69 \%$ has the greatest bitumen capacity, then slags of a capillary-porous structure with a porosity of $37 \%$, slags with a porosity of up to $14 \%$ have the least bitumen capacity.

Asphalt concrete with slag materials has a greater value of residual porosity and, accordingly, a greater rate of water saturation than similar compositions on traditional (granite) mineral materials. Moreover, it should not be considered as a disadvantage, but as a feature of this type of asphalt concrete. Indicator of water saturation, as well as bitumen intensity, depends on the open porosity of the material. Gezentsvey (1956), Kovalev (1991), Rudensky (1992), comparing asphalt with slag materials with highly porous asphalt concrete from natural mineral materials, concluded that they were not sufficiently resistant to water, as well as freeze-thaw cycles.

But observations of the arranged asphalt concrete coatings with slag materials and studies carried out by Kovalev (1991) showed that the coating has a high frost resistance. This is due to the 
peculiarity of asphalt concrete porosity from traditional mineral materials and asphalt concrete with slag materials. In the latter, the residual porosity is mainly represented by closed pores.

Closed porosity creates a rigid structure of the material, the linear expansion coefficient of which is 1.5 times lower than in asphalt concrete from traditional materials. This leads to a decrease in temperature stress with sudden changes in temperature, and increased frost resistance and, consequently, durability of coatings.

The peculiarity of asphalt coatings with slag materials, in comparison with traditional ones, is a longer process of their formation. Rudensky (1992) found that the formation of coatings from asphalt concrete mixtures with slag materials does not occur immediately, but continues for some time. When the traffic intensity is more than 1000 auto/day, the formation of asphalt concrete on slag sand ends in 1-1.5 years, on granulated slags - in 2-5 years from the moment of construction. At the same time, coatings already at the initial stage of operation have high shear resistance and do not exhibit ruts and sagging on them.

During the operation of the coating, with the stabilization of the structure of asphalt concrete, there is a decrease in pore volume, an increase in the density of asphalt concrete, an increase in the value of the angle of internal friction. The greatest increase is observed in the first year, in subsequent years, the angle of internal friction remains almost unchanged. The value of the internal adhesion in asphalt concrete with slag materials is steadily increasing as a result of the strengthening of coagulation structural bonds and irreversible processes that occur in the bitumen film.

When studying asphalt concrete with granulated slags and slag-and-sand sands, the features of preparation, laying and compaction of asphalt concrete with slag materials were established. Thus, on the basis of large-scale studies, it was established that the temperature regime for the preparation of such mixtures is within $110-130{ }^{\circ} \mathrm{C}$, laying in the coating of mixtures on viscous bitumens is possible at a temperature of $70-80^{\circ} \mathrm{C}$, and the sealing temperature is in the range of $50-70^{\circ}$ WITH. Thus, asphalt with slag materials occupies an intermediate position between the hot and cold type of asphalt.

Studies in the US by scientists Hunt, Boyle (2000) describe that in 1994, experimental sites were built in Oregon to assess the use of steelmaking slag in hot asphalt concrete mixes (HMAS). The research covers construction and observation, for five years, of the condition and TEC of a coating made of asphalt concrete, which included $30 \%$ of the slag of steelmaking.

The production of asphalt concrete and the construction of pavement is not difficult, even when crushed steelmaking slag is used as aggregate. If the unit cost of production of asphalt concrete mixtures modified by steelmaking slags is the same as asphalt concrete mixtures of granite materials, the total project costs may increase due to a decrease in the specific surface area due to the use of a more "heavy" mixture made using steelmaking slag production.

For the pilot site for (NMAS), built on $30 \%$ of the steelmaking slag, the specific surface area was $15 \%$ less than when using the traditional "B" type asphalt mix.

Studies conducted in Turkey by scientists Ahmedzade, Sengoz (2009) demonstrate the effect of using steelmaking slag as a mineral material on the properties of hot mix asphalt. Four different types of asphalt mixes were used to prepare Marshall samples, and determine the optimal bitumen content.

The physicomechanical characteristics of all the mixtures were evaluated for stability according to Marshall, the modulus of tensile elasticity, and the determination of the tensile strength. Samples were examined for electrical sensitivity. It was noted that the slags of steelmaking production, used as a mineral material, improved the physical and mechanical properties of asphalt concrete mixtures.

Studies began with an assessment of the toxicity, chemical and physical properties of slags in steelmaking. Then, $0 \%, 25 \%, 50 \%, 75 \%$ and $100 \%$ of the amount of limestone mineral material in the asphalt mixes was replaced with slag material from steelmaking. 
The effectiveness of the slag aggregate of steelmaking was evaluated by improving the indicators of tensile strength, elastic modulus, resistance to groove formation, fatigue life of asphalt concrete samples. It was found that the replacement of up to $75 \%$ of the amount of large limestone aggregate with aggregate from the steelmaking slag (SISP) improved the physical and mechanical properties of asphalt concrete mixtures. The results also showed that a $25 \%$ replacement was the optimal replacement level.

Studies conducted by scientists from Oman, Asi et al. (2007), Hassan, Al-Jabri (2011), report on laboratory testing of granulated copper slag as fine aggregate in hot mix asphalt. The selection of the composition of the mixture according to Marshall was carried out on various mixtures containing up to $40 \%$ of aggregate - copper slag. Testing of the dynamic module as the main indicator of material properties in the Guidelines for the design of road pavement using the mechanical - empirical method (IU - PDG) was carried out at different frequencies (from $0.1 \mathrm{~Hz}$ to $16 \mathrm{~Hz}$ ) and at different temperatures (from $25^{\circ} \mathrm{C}$ to $60{ }^{\circ} \mathrm{C}$ ).

Baseline curves and shear coefficients for the dynamic modulus for control mixtures and slag-containing mixtures were developed. The curves developed were compared with the predictive model according to Witczak for 2 and 3 IU - PDG. The results showed a decrease in strength with increasing slag content in the mixtures compared with the control mixture.

As a result, the aggregate, which includes the steelmaking production slag, due to its physical and chemical properties, is a $100 \%$ recycled product with great potential as a replacement for natural aggregates in road construction. In most works, using aggregates from steelmaking production slag, it is reported that asphalt concrete mixtures with its use have higher porosity, adhesion to the binder, due to the surface structure and chemical composition, favorable particle shape.

High porosity of aggregates from steelmaking slag can increase water resistance in asphalt mixes and improve slip and aquaplaning resistance, and adhesion to bitumen can solve the problem of moisture penetration into underlying layers of pavement due to damage to the surface. These properties contribute to improving the quality of asphalt mixes and coatings with their use, and the level of road safety.

Studies also suggest that asphalt mixtures, including aggregates from steelmaking slags, can also increase resistance to rutting and cracking. From an economic point of view, the use of steelmaking slag, as a filler in road construction, can reduce the cost of mining and processing of natural mineral materials.

The steel industry can also reduce the cost of slags intended for the processing and disposal of a huge amount of slag reserves. While the lifespan of the roadway can be increased, maintenance costs for the coating can also be reduced, thus providing additional funds for other development projects. With regard to the impact on the preservation of the environment, the use of materials from the slag of steel production can in different ways directly reduce both dependence on natural aggregates and the number of projects for the extraction of raw materials.

On the other hand, the inclusion of steelmaking slag in road construction projects can reduce the area used for waste disposal.

Despite the positive qualities of asphalt concrete with slag materials, a number of authors have noted the negative effect of the porosity of slag rubble on the properties of asphalt concrete. Selective diffusion of volatile bitumen fractions into mineral material leads to its aging in the coating. This increases the stiffness of the asphalt concrete, reducing its deformation properties. The increase in coating strength over time is regarded by researchers as a lack of asphalt concrete with slag materials, which leads to the appearance of cracks on the coating in winter.

In order to increase the crack resistance of asphalt concrete coatings with slag materials in winter, it is recommended to use less viscous bitumens, which, without reducing the strength of asphalt concrete, will increase its deformation capacity and slow down aging processes. 
In the case of using new types of mineral materials in asphalt concrete, which differ significantly in their properties from traditional ones, it is necessary to conduct a comprehensive, comprehensive study of not only their physical properties, but also TEP during the service of the road. Assessment of the status of asphalt concrete pavements made of asphalt concrete with slag materials during the operation of the road will make it possible to justify the need for their use in road pavements.

To study the features of the operation of roads with asphalt concrete pavements with slag materials, as the main TEC, you should choose: the strength of the pavement, the flatness of the coating and the coefficient of adhesion. As an indicator that reflects the transport and operational condition of roads, adopted the speed of traffic flow.

Dynamics of changes in the strength of the pavement during operation

One of the main indicators of the transport and operational condition of the road and its efficiency, is the strength of the pavement. The strength of the pavement is estimated by the factor of safety (Cpc), which is defined as the ratio of the average actual modulus of elasticity of the road structure during the billing period of the year (Ef) to the required modulus of elasticity (En) during the existing traffic.

The strength of the pavement is considered sufficient if its actual modulus of elasticity (Ef), determined as a result of field studies, exceeds the required by type of coating and driving conditions (Yn), that is, for the value of the safety factor, there is a ratio:

$$
K_{3 n}>K_{3 n}^{\text {дор }}=0,95>0,85 \text { for roads of different categories, }
$$

where $K_{3 n}^{\text {дор }}$ - the minimum acceptable value of the pavement safety factor.

The actual strength of the pavement varies over the entire period of operation of the road. The nature of the development of deformations is significantly influenced by loads from the movement of vehicles, weather and climate conditions, the stability of the water-thermal regime of the roadbed, the strength properties of the used road-building materials, the quality of construction and the level of operation.

At high positive temperatures and heavy intensive traffic, there is a risk of plastic deformation, which is accompanied by a decrease in the thickness of the coating layer in some places and its increase in adjacent areas. The appearance of such deformations is affected by the color of the coating. Darker coatings due to radiation heating can have a temperature of $15-20{ }^{\circ} \mathrm{C}$ higher than air temperature.

From this point of view, lighter coatings, for example, of asphalt concrete with slag materials, heat up less, i.e., are less susceptible to shear forces.

A decrease in the strength of the road structure also occurs as a result of the occurrence of cracks on asphalt concrete pavement, the appearance of which is characteristic mainly for the cold season - in winter or at a negative temperature in the spring period. The process of changing the elastic modulus of the pavement can be divided into three stages.

The first stage is the formation of the pavement after construction, reconstruction or major repair, during which the roadbed and the structural layers of the pavement are consolidated, rigidity and distribution capacity of the monolithic layers increases, the modulus of elasticity slightly increases, followed by stabilization.

At the second stage, there is a gradual decrease in the strength of the pavement under the influence of the movement of vehicles and weather and climatic factors, which is associated with fatigue processes, grinding of mineral material and a decrease in the distribution capacity of the structural layers. Significantly affect the reduction of strength factors such as: the appearance of cracks and wear of the coating. 
This process continues until the condition (1) is fulfilled for the strength of the road construction, after which the third stage of a sudden loss of strength occurs, which is characterized by significant deformations on the floor and in the structural layers of the pavement.

During this period, due to the active interaction of the wheels of a car with an uneven coating, the deformations that already exist and the appearance of new ones develop rapidly. In the spring, the compaction of the subgrade soil and the sharp decrease in the strength of the road structure occur.

A mathematical model to describe the process of reducing the values of the modulus of elasticity of the pavement within its standard service life $T_{H}$. Theoretical dependencies were obtained for calculating the values of the decrease in the elastic modulus Et during road operation. One of these dependencies is as follows:

$$
E_{t}=a+b\left[\lg \left(\frac{q^{T_{H}+1}-q^{t}}{q^{T_{H}+1}-1}\right) N_{n p}-1\right],
$$

where $a$ - the parameter depends on the type of coating and the group of calculated load, MPa; $b$-parameter that characterizes the effect of load repetition, $\mathrm{MPa} ; q$ - movement rate indicator; $t$-year for which the pavement strength is predicted; $N_{n p}$ - traffic intensity of settlement cars for the current year of operation of the road structure, auto/day.

The evenness of the pavement is an important TEC, which determines the service time between covers of non-rigid pavement coatings and characterizes the safety and comfort of driving on the road. Evenness is determined by a complex of the same parameters as the strength of the pavement and depends on its condition.

The deterioration of the road surface evenness has a significant effect on the speed of travel, comfort of travel, fatigue of drivers and passengers due to harmful vibrations, leading to a decrease in traffic safety and an increase in the cost of transportation.

To determine the dynamics of changes in the flatness of asphalt concrete pavements for the purpose of planning repair work, Krasikov (2000) developed a mathematical model based on the study of the influence on the dynamics of the process of changing the value of the primary flatness. This mathematical model is represented by the following expression:

$$
S_{t}=S_{0}\left[1+c E_{\min }^{d} N_{c}(t)^{a E_{\min }^{b}}\right],
$$

where $S_{0}, S_{t}$, - the value of evenness on the tolkommer after putting the road into operation and for the predicted year $\mathrm{t}$ respectively, $\mathrm{cm} / \mathrm{km} ; N_{c}(t)$ - total traffic intensity, reduced to the design load, auto; $E_{\min }-$ minimum modulus of elasticity, $\mathrm{MPa} ; a, b, c, d$-empirical coefficients.

The mathematical model was used by him to predict the dynamics of flatness changes on traditional asphalt concrete pavements and can be used to conduct comparative assessments with asphalt concrete pavements with slag materials.

The value of the coefficient of adhesion affects the roughness of the coating, which, respectively, the magnitudes and heights of irregularities are divided into macro- and microroughness. The macro-roughness includes irregularities with a length of more than $2-3 \mathrm{~mm}$ and a height of $0.2-0.3 \mathrm{~mm}$, formed by the stone material used in the construction of asphalt concrete pavements or during special surface treatment.

The microroughness is characterized by irregularities with a length of less than 2-3 mm and a height of less than $0.2-0.3 \mathrm{~mm}$ and is determined by the intrinsic roughness of the material. 
The assessment of the surface roughness is carried out using the «sandy spot» method according to DSTU 3587. This method determines the average depth of the roughness of the road surface.

During the operation of the road, the values of micro and macro-roughness of the coating gradually decrease, which leads to a decrease in the value of the coefficient of adhesion.

Analysis of previously conducted research has shown that the nature and intensity of changes in micro and macro roughness depends on the following indicators:

- mechanical (rolling friction, sliding friction and shock load from the car wheel);

- climatic (temperature change, humidity);

- properties of the mineral material, which is part of the asphalt concrete (grain, porosity, the degree of weathering of the rock);

- the amount of abrasive on the coating (dust, coating wear products).

The main reason for reducing the roughness (wear) of the coating are mechanical indicators, depending on the intensity and composition of the traffic flow.

As a result of their impact, there is a constant exposure and grinding of large mineral grains of asphalt concrete. A significant increase in the intensity of the movement of heavy trucks leads to an acceleration of the process of grinding gravel grains.

The degree of reduction in the coefficient of adhesion, especially in the first year of operation of the coating, is significantly influenced by the initial height of macroscopic irregularities and the size of rubble. If gravels provide a sufficiently high macroroughness, then the decrease in the coefficient of adhesion is small. When the protrusions of the macroroughness of the pavement are worn, the shape of the protrusions of the mineral material changes, the gravel is reoriented in space, and its upper part becomes rounded.

Grinding grains of gravel helps to reduce the value of the coefficient of adhesion, which stabilizes, reaches its minimum value and then does not change, but is determined only by the microroughness of the stone material.

Simultaneously with polishing, the reverse process occurs - weathering, which is especially enhanced in the winter period. As a result of the complex of weather and climatic factors, microcracks arise in the stone material, which gradually increase and lead to the destruction of its surface layer. In this regard, on roads with low traffic, the surface of the coating for a long time retains the necessary microroughness. With a significant traffic flow, the grinding process in intensity is much higher than the weathering process.

Studies have shown that the greatest residual microroughness and, consequently, the highest minimum value of the coefficient of adhesion, is characterized by asphalt concrete based on different strength and heterogeneous materials.

As a result of long-term observations of traditional asphalt concrete pavements, a graphic dependence of the dynamics of change in the friction coefficient on the micro and macro roughness of the coating, which, in turn, depends on the intensity and composition of the traffic flow, has been established. The general pattern of changes in the roughness of the coating is presented in the form:

$$
R(t)=a \cdot e^{-b} N_{p}+c,
$$

where $R(t)$ - averaged height of macro roughness, $\mathrm{mm} ; N_{p}$ - number of cars passing; $a, b, c$ - coefficients depending on crushed stone size, coating hardness and traffic flow composition.

This graphical dependence can be used to compare the dynamics of changes in the value of the coefficient of adhesion of asphalt concrete pavements made of asphalt concrete with slag and traditional mineral materials.

In this chapter the system approach to the construction of mathematical models for the definition of basic riding qualities highways changes with traditional and asphalt pavements produced of slag materials is considered. 
Change of strength of a pavement due to various factors can be presented in the form of the following mathematical model:

$$
E_{\phi}(t)=f_{1}\left(N, S_{t p}, m, v, p\right),
$$

where $N$ - is a traffic volume, vehicle/day; $S_{t p}$ - composition of traffic flow; $m$ - a set of the parametres describing pavement design and strength properties of used materials; $v$-a set of the parametres describing the influence of weather-climaticfactors; $p$-a set of the parametres describing the influence of measures on construction and operational maintenance of road.

Accoding to the results of conducted researches, the change of an actual modulus of the pavement's strength at the stage of highway maintenance can be described as a three stages process, and its dynamics can be presented as a graph in Fig. 1.

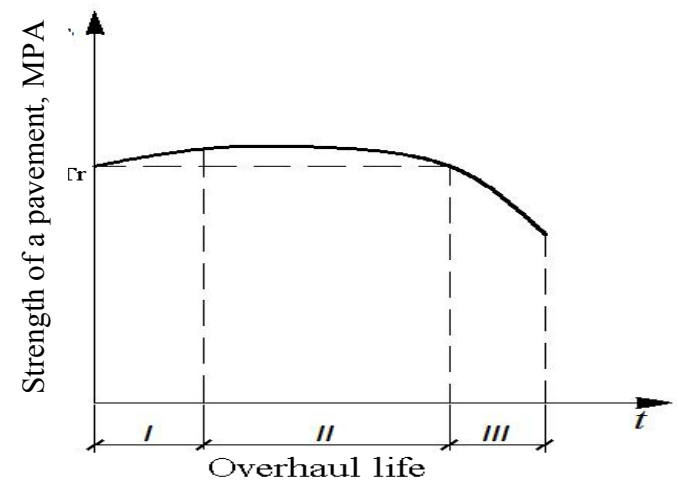

Fig. 1. Change of strength of a pavement during inter-repair period

The dynamics of evenness of an asphalt pavement, $S(t)$ can be presented in the form of the following mathematical model:

$$
S(t)=f_{2}\left(N, S_{t p}, E, m, v, p\right)
$$

where $E$ - pavement modulus, MPa.

Regularity of change of evenness of asphalt pavements during inter-repair periods $\left(t_{\partial . n .}\right)$ is presented in the form of a graph in the Fig. 2.

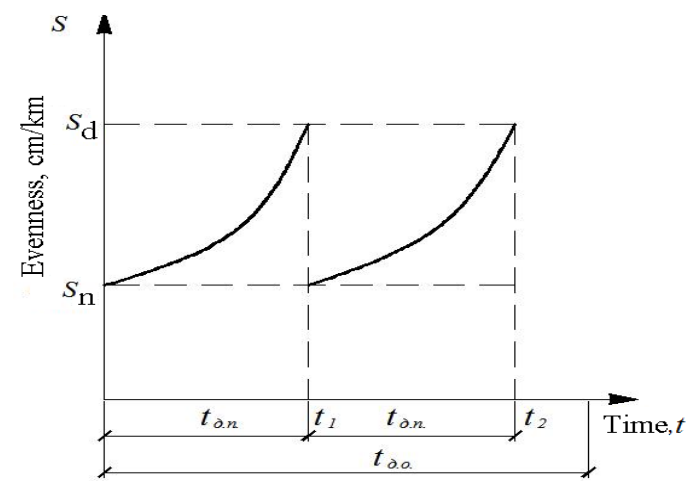

Fig. 2. Change of evenness of asphalt pavement during highway operation 
According to the research results, change of cohesion factor value of an asphalt pavement in the course of a long-term maintenance after the construction or repair of a highway can be presented in the form of the graph (see Fig. 3) and the following mathematical model:

$$
k_{c u}=f_{3}\left(N_{p}, S_{t p}, m, v, p\right),
$$

where $N_{p}-$ total number of passed design vehicles during operation.

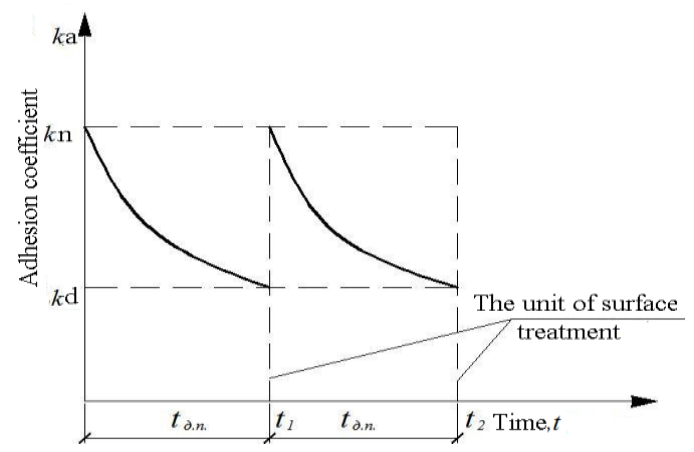

Fig. 3. Change of cohesion factor value of asphalt pavement during highway operation

Change of cohesion factor value from standard values $(k)$ to admissible $\left(k_{\text {дon. }}\right)$ ones, results from the impact of mechanical and natural-climatic factors on a highway.

The process of cohesion factor value change during the period of winter slipperiness formation and in terms of works on its liquidation can be presented in the form of the graph on Fig. 4.

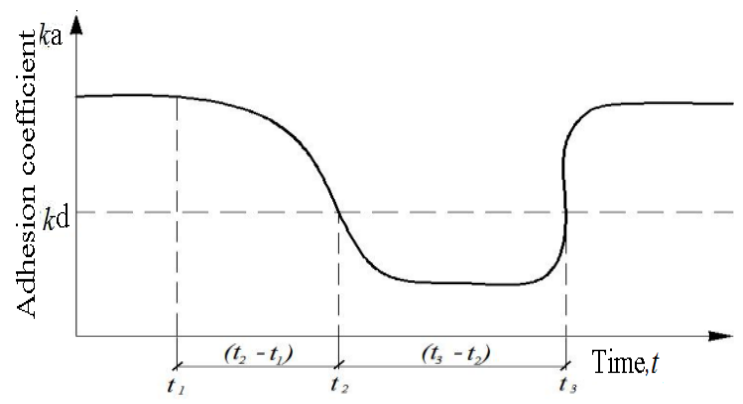

Fig. 4. Change of cohesion factor value on asphalt pavement during the period of winter slipperiness formation and its liquidation

As a result of slipperiness formation during the change of weather conditions (time span $t_{2}-$ $t_{1}$ ) cohesion factor value decreases below admissible value $\left(k_{\partial o n}\right)$, with regard to traffic safety requirements. When taking the anti-slipperiness measures (time span $t_{3}-t_{2}$ ), cohesion factor remains below admissible value, and after «the effects» produced by de-icing materials - its value increases, thereby improving riding qualities of a highway.

According to the statement of a problem, an interaction scheme of external and internal parametres of the subsystem «Road-Car-Environment» was developed.

Internal parametres of the subsystem influencing the dynamivs of riding qualities change are divided into two groups: 
- Inherent parametres of the subsystem to which refer road $\overline{d(t)}$ and $\overline{h(t)}$ transport parametres;

- Parametres affecting the environment to which refer weather-climatic $\overline{v(t)}$ factors.

As an external (initial) parameter of the subsystem 'Road-Car-Environment' the following basic riding qualities of a highway can be mentioned: strength of road pavement, evenness of a pavement, cohesion factor and a generalising parameter - traffic flow speed. For the problem solution it is necessary to consider the dynamics of their change in time.

Thus, mathematical model for the description of changes of basic riding qualities in a longterm gap in the subsystem 'Road-Car-Environment' looks like that:

$$
\overline{y^{\prime}(t)}=F_{\text {Д-A-C }}\left[\overline{v^{\prime}(t)}, \overline{d^{\prime}(t), \overline{t^{\prime}}}\right\rfloor
$$

where $\overline{y(t)}=\left\{E_{\phi}(t), S(t), k_{c u}(t), V(t)\right\}-$ Vector of external parameters of the subsystem; $F_{\text {Д-A-C }}$ - the law of operation of the subsystem; $\overline{v(t)}=\left\{v_{1}(t), v_{2}(t), v_{3}(t)\right\}$ - vector of external environment impact (weather and climatic parameters); $\overline{d(t)}=\left\{m_{1}, m_{2}, E_{0}, S_{0}, R_{0}\right\}$ - vector of parameters of their own subsystems (traffic specification); $\overline{h(t)}=\left\{N(t), N_{p}(t), S_{t p}(t)\right\}-$ vector of inherent parameters of the subsystems (road parameters); $t$ - time.

As an external parameter of the subsystem «Environment - Road» the state the road surface in winter is accepted. To solve the problem slippery condition of the pavement is considered, i. e. presence of slipperiness as a glassy ice on its surface.

Thus, mathematical model for describing the state of the pavement for shor intervals of time during winter in the subsystem «Environment - Road» is as follows:

$$
\overline{y^{\prime}(t)}=F_{\mathrm{c}-д}\left[\overline{v^{\prime}(t)}, \overline{d^{\prime}(t), t^{\prime}}\right] \text {, }
$$

where $\overline{y^{\prime}(t)}=\left\{S_{p}\right\}$ - vector which components are the state of the road pavement in winter; $F_{\text {с-д }}$ - the law the subsystem operation; $\overline{v^{\prime}(t)}=\left\{T(t), v_{1}^{\prime}(t), v_{2}^{\prime}\right\}$ - vector of environmental impact (weather parameters); $\overline{d^{\prime}(t)}=\left\{m_{1}^{\prime}, m_{2}^{\prime}, \ldots, m_{5}^{\prime}(t), T_{n}^{\prime}(t)\right\}$ - vector of inherent parameters of the subsystem (road parameters); $t^{\prime}-$ time during which winter slipperiness formation as a glassy ice is possible.

To assess the dynamics of elastic modulus change of road pavement with the surfacing of asphalt concrete produced using traditional materials, mathematical models developed by Krasikov (2000) were used.

For a relatively small deformations of road pavement, that is,during the first and the second stages of road design work, its strength $E_{\phi}(t)$ is described using the following mathematical model:

$$
E_{\phi}(t)=E_{0}\left\{1-\left[a_{m}+b_{m}\left(\lg N_{c}(t)+\lg t\right)\right]\right\},
$$

where $E_{0}$ - mathematical expectation of elasticity modulus during the first year of road pavement life after the completion of its formation, MPa; $a_{m}$ and $b_{m}$ - the parameters of the equation defined on the basis of experimental studies; $N_{c}(t)$ - total traffic volume calculated to the design load of the group A, vehicles / day; $t$ - predicted period of service of the pavement, in years.

The study of dynamics of evenness of traditional asphalt pavemenst had been based on the following mathematical model, also proposed by Krasikov (2000):

$$
S_{t}=S_{0}\left\lfloor 1+c E_{\min }^{d} N_{c}(t) a E_{\min }^{b}\right\rfloor
$$


where $S_{0}$ - the value of evenness according to impact measuring device after putting the road into operation, $\mathrm{cm} / \mathrm{km} ; E_{\min }$ - the minimum modulus of elasticity, MPa; $a, b, c, d$-parameters of the equation defined on the basis of experimental studies.

It is possible to assess the change of riding qualities of the roads with the surfaces made from slag and traditional asphalt materials during short time intervals (in winter) through the study of the processes of various types of winter slipperiness formation on their surfaces.

Mathematical formulation of the problem contains the differential equation and singlevaluedness condition including thermal parameters and dimensions of the road structure, as well as the boundary conditions and the initial temperature distribution. Temperature conditions of the road structure on the surface under the influence of temperature, which changes periodically, for the issue under consideration can be described as a monospaced heat conductivity equation:

$$
c \rho \frac{\partial T(x, t)}{\partial t}=\frac{\partial}{\partial x}\left[\lambda \frac{\partial T(x, t)}{\partial x}\right]+q
$$

where $T(x, t)$ - temperature inside the road structure and subgrade soil at the depth of $x$ at time $t,{ }^{\circ} \mathrm{C} ; q$ - heat flow density in the structure, $\mathrm{W} / \mathrm{m}^{3} ; c-$ specific heat capacity, $\mathrm{J} / \mathrm{kg} \mathrm{K} ; \rho$ - density of the material, $\mathrm{kg} / \mathrm{m}^{3} ; \lambda-$ thermal conductivity, $\mathrm{W} / \mathrm{m} \mathrm{K}$.

As road pavement is a multilayered system, equation (8) for the issue under consideration is transformed into a system of differential equations:

$$
\left\{\begin{array}{ll}
c_{i} \rho_{i} \frac{\partial T}{\partial t}=\frac{\partial}{\partial x}\left(\lambda_{i} \frac{\partial T}{\partial x}\right) & H_{i-1} \leq x \leq H \\
c_{M} \rho_{M} \frac{\partial T}{\partial t}=\frac{\partial}{\partial x}\left(\lambda_{M} \frac{\partial T}{\partial x}\right) & H_{4} \leq x \leq H_{\phi} \\
c_{T} \rho_{T} \frac{\partial T}{\partial t}=\frac{\partial}{\partial x}\left(\lambda_{T} \frac{\partial T}{\partial x}\right) & H_{\phi} \leq x \leq H
\end{array} .\right.
$$

On condition on the boundary of the phase transition in the soil of subgrade:

$$
\left.\left.\lambda_{m} \frac{\partial T}{\partial x}\right|_{x=H_{\phi}} \lambda_{T} \frac{\partial T}{\partial x}\right|_{x=H_{\phi}}=Q_{\rho} \frac{\partial H_{\phi}}{\partial t},
$$

where $H_{\phi}=H_{\phi}(x, t)$ of the phase transition, $\mathrm{m} ; Q$ - latent heat of ice melting, $\mathrm{kJ} / \mathrm{kg}$.

The rate of destruction of ice formation on the surfaces of pavements under the impact of passing vehicles and the quality of cleaning depends on the force of adhesion (adhesion) of these formations to the surface of the pavement.

Bond strength of ice and material of the surface $\left(R_{c u}\right)$ is defined as the difference of bending strength of frozen and tested at a given temperature saturated $\left(R_{6}\right)$ and dried $\left(R_{c y x}\right)$ samples:

$$
R_{c u}=R_{B}-R_{c y x}
$$

or

$$
R_{c u}=\frac{3}{2} \cdot \frac{1}{b h^{2}}\left(R_{b}-R_{c y x}\right),
$$


where $P_{6}, P_{c y x}$ - breaking load; $l$ - distance between the supports; $b$ - width of the sample; $h$ - height of the sample.

Determination of bonding strength of ice with asphalt pavement surface produced using traditional materials and slag according to this method allows to determine the differences in winter slipperiness formation on these types of pavements.

Evaluation of the strength of the pavement was carried out by determining the modulus of elasticity in characteristic areas annually for five years of operation of the road. The modulus of elasticity was defined as the elastic deflection of the pavement, obtained by the method of static load wheel of the car. For testing, a loaded two-axle dump truck MAZ-503A was used. To measure the deflection, a PC-204 deflector was used with a deflection accuracy of $\pm 0.01 \mathrm{~mm}$. Evaluation of the strength of the pavement and processing of research results was carried out in accordance with VBN B.2.3-218-186.

Processing the results of determining the elastic deflection was carried out on the basis of mathematical statistics methods. The actual deflection of the pavement was determined for the normative level of reliability $\mathrm{Kn}=0.90$. The modulus of elasticity at the site was determined by the formula:

$$
E_{\phi r}=\frac{0,36 Q_{K}}{l_{\phi}},
$$

where $E_{\phi \pi}$ - the modulus of elasticity of the road structure at the control point at a given time, MPa; $Q_{K}-$ wheel load, $\mathrm{\kappa H} ; l_{\phi}-$ actual deflection at reliability $K_{H}=0,90, \mathrm{~cm}$.

If the field studies were conducted in the off-design period of the year, then in order to obtain an objective characteristic of the state of the road pavement, a corresponding adjustment was made. The actual modulus of elasticity, reduced to the estimated period of the year and estimated temperature, was determined according to VBN B.2.3-218-186, respectively. The calculation was carried out according to the formula:

$$
E_{\phi}=E_{\phi л}\left[\frac{1}{K_{\Theta}}-\frac{1,5 D K_{\Gamma}}{H_{K}}\left(1-\frac{W_{\phi л}}{W_{p}}\right)\right] \kappa_{д} K_{T},
$$

where $K_{\Theta}$ - temperature coefficient equal to the ratio of the deflection at the calculated temperature of the coating to the deflection at a temperature corresponding to the test period; $D$-calculated wheel print diameter, $33 \mathrm{~cm} ; K_{\Gamma}-$ the empirical coefficient, depending on the type of subgrade soil at the test point, is assumed $K_{I}=2,15$ - for loam, silty dust loam; $H \kappa$ - pavement thickness, $\mathrm{cm} ; W_{\phi}, W_{p}$ - measured and calculated relative humidity of the roadbed during the test period; $K_{\partial} u K_{m}$ - empirical coefficients.

Analysis of the obtained results shows that the values of the elastic moduli in 2013-2018 exceed the required one, which is assumed to be equal to $243 \mathrm{MPa}$. The minimum value of the modulus of elasticity, equal to $226 \mathrm{MPa}$, on which the tests were carried out almost immediately after the completion of work on laying the top layer of the coating of asphalt concrete with slag materials.

It should be noted that the entire cycle of construction work on this section was carried out from August to October, at the time when in other sections the embankment of the roadbed was poured in 2015, that is, it had a year of exposure before the pavement device. One year after operation, the values of the elastic moduli in the sections were leveled and had approximately the same values in both areas. 


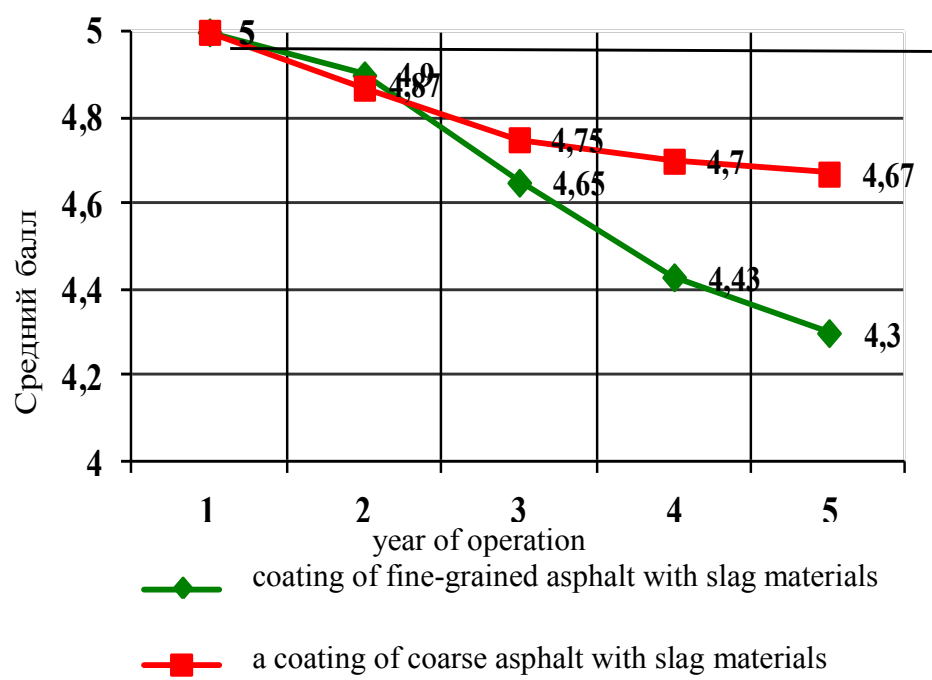

Fig. 5. Change in scoring used for evaluation of road pavement condition with fine and coarse bituminous concrete surfacing produced of slag materials
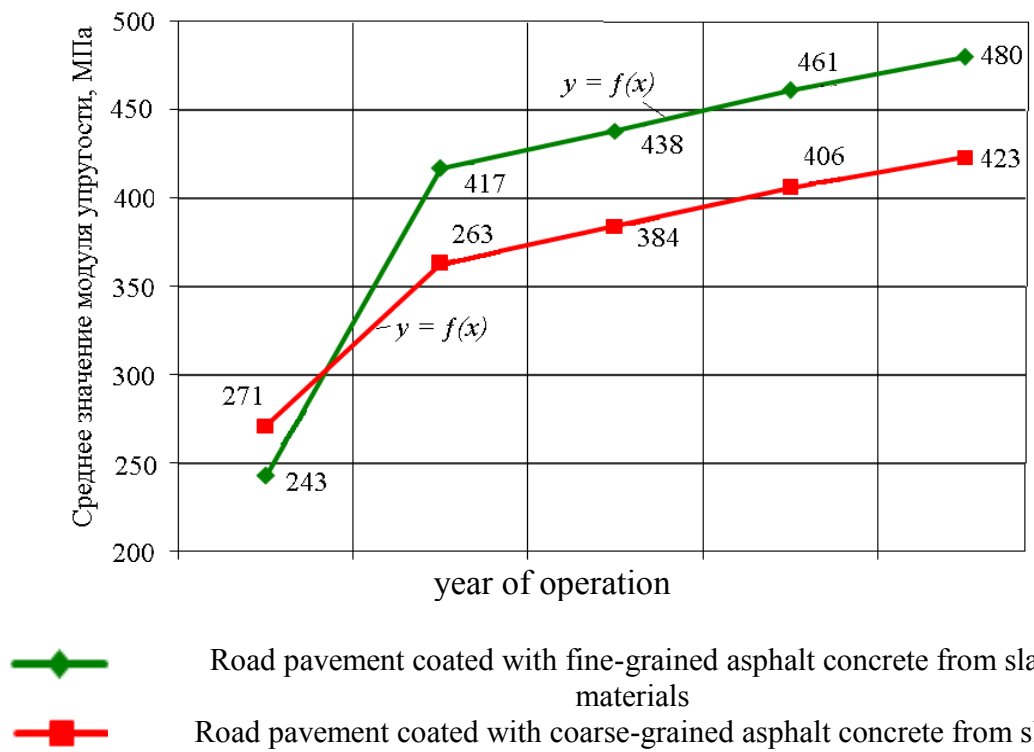

Road pavement coated with fine-grained asphalt concrete from slag materials

Road pavement coated with coarse-grained asphalt concrete from slag materials

Fig. 6. Change in the elastic modulus values of pavement with the surfacing of fine and coarse bituminous concrete produced of slag materials

When monitoring the strength of the pavement during the operation period, an increase in the strength of the road structure was noted. This feature can be explained by the processes of hydration that occur in the layers of the slag base, which lead to their monolithic, and thereby hardening of these layers. On the basis of the conducted studies, it is possible to predict a further increase in structural strength, which will ensure reliable operation of the pavement under the influence of increasing transport loads. 


\section{Recommendations:}

1. Overhaul life for the highways with asphalt pavements produced of slag materials should be of the same duration as for the roads with asphalt pavements produced of traditional materials but taking into consideration intensity of traffic flow, type of pavement, safety factor and roadclimatic zone.

2. Service life of asphalt pavement produced of slag materials should be evaluated by the degree of surface pavement wear and reduction of the modulus of elasticity of the pavement by more than $25 \%$ of the values obtained on the basis of diagnostic tests.

3. For the repair of asphalt pavements produced of slag materials it is recommended to use the most efficient and cost-effective technologies based on the principles of regeneration.

4. The main defect of asphalt pavement with slag materials are cracks. At its operational maintenance it is necessary to fill the cracks with mastic or viscous bitumen during the transition from summer to winter operational period.

Conclusions:

1. The fulfilled study aimed at determining the most important factors that affect the change of riding qualities of asphalt pavements with slag materials proved that for the assessment of changes in the strength, evenness and cohesion factor of the pavement overhaul life can be adopted, and to assess the road conditions in winter - the time interval, corresponding to the formation of winter slipperiness can be used.

2. Experimental research has confirmed that the possibility of winter slipperiness formation as a glassy ice on the asphalt pavement with slag materials due to higher thermal inertia - is by $15 \%$ lower than on the asphalt pavements produced of traditional materials, and the value of bonding strength with ice is almost 2 times lower than it is for the surface pavements produced of traditional materials.

3. For the first time it was theoretically substantiated and experimentally confirmed that the riding qualities, namely, strength, modulus of elasticity estimated for 5 years of operation for coarse and fine-grained asphalt from slag materials increased by $55 \%$ compared with the initial ones; evenness increased by $10 \%$, cohesion factor remained virtually unchanged for the coarsegrained asphalt (initial value was 0.57, and after 5 years of operation -0.53 ) and it increased for fine-grained asphalt concrete (respectively 0.37 and 0.46 ).

\section{PЕФЕРАТ \\ Катерина Краюшкіна ${ }^{1}$, Андрій Бєлятинськийㄹ, Тетяна Химерик² \\ ${ }^{1}$ Державне підприємство «ДерждорНДІ», \\ ${ }^{2}$ Наиіональний авіачійний університет, ekrayushkina15@ukr.net \\ ОСОБЛИВОСТІ ВЗАЕМОДІї ОРГАНІЧНОГО В'ЯЖУЧОГО ТА ШЛАКОВОГО НАПОВНЮВАЧА}

У статті приведені результати досліджень взаємодії органічних в'яжучих 3 шлаковими матеріалами в асфальтобетонних сумішах. Визначено, що шлаковий щебінь, оброблений в'яжучим, являє собою високоякісний матеріал, який широко застосовують для будівництва покриттів і основ. Обробка щебеню в'яжучим забезпечує його повне обволакування плівкою завданої товщини. Товщина плівки пов'язана як 3 в'язкістю в'яжучого, так і з властивостями шлакового щебеню. Чим більше в'язкість в'яжучего, тим тоньше плівка на зернах. Із зменшенням розміру зерен зменшується і товщина плівки, із збільшенням шорсткості зерен товщина плівки в'яжучого збільшується. При ущільненні за рахунок наближення зерен, вкритих в'яжучим, утворюються коагуляційні зв'язки, які мають достатню міцність і високу водостійкість. Порівняно з способом просочування і змішування на дорозі цей спосіб дає економію в'яжучого.

Ключові слова: органічне в'яжуче, шлаковий матеріал, асфальтобетон, фізико-механічні характеристики. 


\section{PЕФЕРАТ \\ Екатерина Краюшкина ${ }^{1}$, Андрей Белятынский², Татьяна Химерик ${ }^{2}$ \\ ${ }^{I}$ Государственное предприятие "ДерждорНДІ», \\ ${ }^{2}$ Национальный авиаиионый университет, ekrayushkina15@ukr.net ОСОБЕННОСТИ ВЗАИМОДЕЙСТВИЯ ОРГАНИЧЕСКОГО ВЯЖУЩЕГО И ШЛАКОВОГО НАПОЛНИТЕЛЯ}

В статье приведены результаты исследований взаимодействия органических вяжущих со шлаковыми материалами в асфальтобетонных смесях. Определено, что шлаковый щебень, обработанный вяжущим, представляет собой высококачественный материал, который широко применяют для строительства покрытий и оснований. Обработка щебня вяжущим обеспечивает его полное обволакивание пленкой заданной толщины. Толщина пленки взаимосвязана как с вязкостью вяжущего, так и со свойствами шлакового щебня. Чем больше вязкость вяжущего, тем тоньше пленка на зернах. С уменьшением размера зерен уменьшается и толщина пленки, с увеличением шероховатости зерен толщина пленки вяжущего возрастает. При уплотнении за счет сближения зерен, покрытых вяжущим, образуются коагуляционные связи, обладающие достаточной прочностью и высокой водостойкостью. По сравнению со способом пропитки и смещения на дороге этот способ дает экономию вяжущего.

Ключевые слова: органическое вяжущее, шлаковый материал, асфальтобетон, физикомеханические характеристики.

$$
\begin{gathered}
\text { ABSTRACT } \\
\text { Kateryna Krayushkina }{ }^{1} \text {, Andriy Belyatynsky }{ }^{2} \text {, Tetiana Khymeryk }{ }^{2} \\
{ }^{\text {SState company }} \text { "DerzhdorNDI», } \\
{ }^{2} \text { National Aviation University, ekrayushkina15@ukr.net }
\end{gathered}
$$

\section{FEATURES OF INTERACTION OF ORGANIC BINDER AND SLAG FILLER}

The article presents the results of studies of the interaction of organic binders with slag materials in asphalt concrete mixtures. It is determined that slag crushed stone treated with a binder is a high-quality material that is widely used for the construction of coatings and bases. The processing of crushed stone with a binder ensures that it is completely covered with a film of a given thickness. The thickness of the film is interrelated with both the viscosity of the binder and the properties of slag rubble. The greater the viscosity of the binder, the thinner the film on the grains. With a decrease in the grain size, the film thickness also decreases, with an increase in the grain roughness, the thickness of the binder film increases. During compaction, coagulation bonds are formed due to the convergence of the grains coated with the binder, which have sufficient strength and high water resistance. Compared with the method of impregnation and displacement on the road, this method saves the binder.

Key words: organic binder, slag material, asphalt concrete, physical and mechanical characteristics.

\section{REFERENCES}

1. Gustafson K. Road icing on different pavements structures. Investigation at Fest-Field Lincoping 19761980 / K. Gustafson // Rapp. Statens vogjch tratikinst. - 1981. - 216A(12). - 174 p.

2. Untersuchungen zum Griffigkeitsverhalten von Splittmastixasphalt-Deckschichten / S. Huschek, J. Dames, J. Kanyi, J. Lindner // Forschung, Strassenbau und Strassenverkchrstechnik. - 2002. - 837. - P. 1-53.

3. Ahmedzade P. Evaluation of steel slag coarse aggregate in hot mix asphalt concrete / P. Ahmedzade, B. Sengoz // Journal of Hazardous Materials. - 2009. - 165 (1-3). - P. 300-305.

DOI: dx.doi.org/10.1016/j.jhazmat.2008.09.105.

4. Asi I. M. Use of steel slag aggregate in asphalt concrete mixes / I. M. Asi, H. Y. Qasrawi, F. I. Shalabi // Canadian Journal of Civil Engineering. - 2007. - 34(8). - 902-911. DOI: dx.doi.org/10.1139/107-025.

5. Aide au choix des couches de roulement vis-à-vis de l'adherence / [G. Aussedat, A. Barbiero, A. Baudon et al.]. // Revue Generale des Routes. - 2003. - 813. - P. 59-61.

6. Environmental impacts of steel slag reused in road construction: A crystallography and molecular (XANES) approach / [P. Chaurand, J. Rose, V. Briois, L. Olivi et al.]. // Journal of Hazardous Materials. - 2007. - 139(3). - P. 537-542. DOI: dx.doi.org/10.1016/j.jhazmat.2006.02.060. 
7. Dependence of the recycled asphalt mixture physical and mechanical properties on the grade and amount of rejuvenating bitumen // D. Čygas, D. Mučinis, H. Sivilevičius, N. Abukauskas // The Baltic Journal of Road and Bridge Engineering. - 2011. - 6(2). - P. 124-134. DOI: dx.doi.org/10.3846/bjrbe.2011.17.

8. Deniz D. Evaluation of expansive characteristics of reclaimed asphalt pavement and virgin aggregate used as base materials / D. Deniz, E. Tutumluer, J. S. Popovics // Transportation Research Record. - 2010 - 2167. - P. 10-17. DOI: dx.doi.org/10.3141/2167-02.

9. Emery J. Stylink polymer modified asphalt cementpavement performance evalution / J. Emery // Geotechnical Engineering Limited (JEGEL). - 1999. - 12. - P. 1-27.

10. Hassan H. F. Laboratory evaluation of hot-mix asphalt concrete containing copper slag aggregate / H.F. Hassan, K. Al-Jabri // Journal of Materials in Civil Engineering. - 2011. - 23(6). - P. 879-885. DOI: dx.doi.org/10.1061/(ASCE)MT.1943-5533.0000246.

11. Hunt L. Steel Slag in Hot Mix Asphalt Concrete. Final Report State Research Project \#511 / L. Hunt, G.E. Boyle. - Oregon Department of Transportation. USA. [Electronic reference]. - 2000. - 19 p. - Access mode: http://www.oregon.gov/ODOT/TD/TP_RES/.

12. $L i W$. Laboratory test study on asphalt concrete with steel slag aggregates / W. Li, P. Sun, C. Zhang // Applied Mechanics and Materials. - 2012. - 152-154. - P. 117-120.

13. Sivilevičius, $H$. 2011. The use of constrained and unconstrained optimization models in gradation design of hot mix asphalt mixture / H. Sivilevičius, V. Podvezko, S. Vakrinienè // Construction and Building Materials. - 2011. - 25(1). - P. 115-122. DOI: dx.doi.org/10.1016/j.conbuildmat.2010.06.050.

14. Use of steel slags in automobile road construction / K. Krayushkina, O. Prentkovskis, A. Bieliatynskyi, R. Junevičius // Transport. - 2012. - 27(2). - P. 129-137. 